\title{
KARAKTERISTIK DAN FUNGSI INTERMEDIASI PERBANKAN DI INDONESIA
}

\section{Renniwaty Siringoringo ${ }^{1}$}

\begin{abstract}
This paper analyzes the influence of ownership and specific characteristic of banks on the capital structure and the intermediation function of commercial banks in Indonesia. Using multivariate regression on bank level data of 2006-2009, the result shows the ownership structure, profitability, size, and management expense affect the bank capital structure, with a total effect of 50.14\%. Towards the bank intermediation, with a total effect of $27.01 \%$, the ownership structure, profitability, bank size, credit risk, expense management and capital structure influence the banks intermediation function.
\end{abstract}

Keyword: Ownership structure, specific characteristic of bank, capital structure and bank intermediation function

JEL Classification: G21, G32

1 Lecturer at Putera Batam University, Batam, Kepulauan Riau : renni_ringo@yahoo.com. 


\section{PENDAHULUAN}

Fungsi bank sebagai lembaga intermediasi khususnya dalam penyaluran kredit mempunyai peranan penting bagi pergerakan roda perekonomian secara keseluruhan dan memfasilitasi pertumbuhan ekonomi. Dimana pada level ekonomi makro bank merupakan alat dalam menetapkan kebijakan moneter sedangkan pada level mikro ekonomi bank merupakan sumber utama pembiayaan bagi para pengusaha maupun individu (Konch, 2000).

Pengalokasian dana yang cukup besar untuk penyaluran kredit bank membutuhkan pembiayaan yang cukup besar, karena jika tidak, akan mengganggu likuiditas bank. Setiap rencana ekspansi kredit harus didukung oleh adanya tambahan modal, karena apabila tidak maka ekspansi kredit akan berdampak terhadap menurunnya CAR bank. Sehingga penting bagi manajemen bank untuk menentukan kebijakan struktur modal dalam mendukung kegiatan operasional bank, khususnya dalam menyalurkan kredit. Kebijakan struktur modal merupakan suatu kebijakan yang menyangkut kombinasi yang optimal dari penggunaan berbagai sumber dana yang akan digunakan untuk membiayai suatu investasi dan juga untuk mendukung operasional perusahaan dalam usaha untuk meningkatkan laba (profit) perusahaan dalam rangka mencapai nilai perusahaan yang tinggi (Gitman, 2009).

Struktur modal institusi keuangan termasuk bank secara fundamental berbeda dengan perusahaan non-financial, karena karakteristik bisnis atau kegiatan operasionalnya berbeda. Selain itu, bank harus memiliki buffer sesuai dengan ketentuan atau regulasi penyediaan modal inti minimum yang ditentukan oleh otoritas moneter dalam hal ini bank sentral, agar mampu melindungi dana deposannya (Saunders, 2008). Struktur permodalan yang optimal merupakan target yang senantiasa dicapai oleh suatu perusahaan termasuk bank. Teori tradeoff atau balancing-theory menjelaskan bahwa untuk mencapai struktur modal yang optimal tersebut maka perusahaan harus dapat memadukan suatu keseimbangan atas trade off antara manfaat atau pengembalian (return) dan risiko atau biaya yang dihadapi sehingga dapat memaksimalkan nilai perusahaan (Brigham, 2005). Selain itu bank juga dihadapkan pada permasalahan sumber pendanaan yang mana yang didahulukan penggunaannya sesuai dengan pecking order theory.

Beberapa hasil penelitian mengenai pemilihan sumber dana untuk menentukan struktur modal yang optimal, menunjukkan hasil yang berbeda. Hasil kajian empiris yang dilakukan oleh Darwanto (2008) terhadap bank devisa di Indonesia, mengenai hubungan leverage dengan pemilihan sumber dana antara debt dan equity, menunjukkan bahwa leverage memiliki hubungan yang negatif, yang berarti bahwa bank devisa harus meningkatkan modal sendiri dibanding harus bergantung pada hutang untuk mengoptimalkan nilai perusahaannya. Hal ini sejalan dengan penelitian Kishan dan Opiela (2000) yang menemukan bahwa pertumbuhan penyaluran kredit dipengaruhi oleh ukuran bank (asset) dan modal bank (leverage ratio) yaitu melalui penambahan ekuitas (modal sendiri). Berbeda dengan kajian yang dilakukan oleh Inderst \& Mueller (2008), hasil penelitian menunjukkan bahwa dengan asumsi tanpa adanya 
regulasi, leverage ratio melalui penambahan utang (debt) memiliki korelasi yang positif terhadap tingkat pemberian kredit yang beresiko.

Selain penentuan sumber-sumber pendanaan, kebijakan struktur modal yang optimal juga dipengaruhi oleh struktur kepemilikan. Struktur kepemilikan biasanya berhubungan dengan proporsi kepemilikan saham oleh shareholders yang memberikan hak bagi mereka untuk mengontrol (source of power) dan ikut mengambil kebijakan-kebijakan dalam perusahaan. Struktur kepemilikan bank di Indonesia dilihat dalam perspektif kontrol perbankan dibagi atas empat yaitu kepemilikan terkonsentrasi, kepemilikan pemerintah, swasta domestik dan kepemilikan asing (Taswan, 2010). Besarnya kepemilikan oleh individu mengindikasikan bahwa struktur kepemilikan bank di Indonesia adalah terkonsentrasi pada sejumlah pemilik. Konsekuensinya manajer hanya merupakan perpanjangan tangan pemegang saham pengendali. Keputusan manajer tunduk dan sejalan dengan kepentingan pemegang saham mayoritas/ pengendali.

Persaingan yang semakin ketat dalam industri perbankan dan dalam rangka menghadapi era globalisasi, kebijakan perbankan nasional diarahkan pada terwujudnya struktur perbankan Indonesia yang sehat, kuat dan efisien. Salah satu langkah yang dilakukan adalah dengan implementasi API (Arsitektur Perbankan Indonesia ) melalui kebijakan konsolidasi yang ditujukan pada aspek permodalan dan aspek kepemilikan perbankan. Kebijakan tersebut membuat peta struktur kepemilikan bank mengalami pergeseran, dimana banyak bank-bank domestik dikuasai oleh bank asing. Peningkatan investasi asing terhadap perbankan domestik mengubah kepemilikan yang secara otomatis akan meningkatkan kontrol dan pengendalian pihak asing terhadap perbankan domestik terutama dalam penguasaan pangsa pasar.

Kebijakan dan sistem kontrol yang berubah karena struktur kepemilikan yang berubah, kemungkinan dapat mempengaruhi karakteristik spesifik specifik bank. Athanasoglou et.al, 2005 mengemukakan bahwa karakteristik spesifik specifik bank merupakan faktor-faktor yang berasal dari kondisi internal perusahaanatau bank yang bersifat mikro yang dapat dilihat dari neraca dan laporan laba rugi bank. Karakteristik spesifik specifik bank ini dapat dilihat dari tingkat permodalan bank (kapital), ukuran bank (size), profitabilitas atau tingkat keuntungan, risiko kredit, produktivitas, beban manajemen dll.

Jika dilihat fenomena yang terjadi pada perbankan di Indonesia saat ini, yaitu bahwa kinerja keuangan bank umum beberapa tahun ini mengalami perkembangan yang sangat baik dan positif. Hal ini tercermin dari pertumbuhan asset, rasio permodalan (CAR) dan tingkat profitabilitas (ROA) yang cukup tinggi, kondisi likuiditas yang relatif terkendali serta risiko kredit macet (NPL) yang rendah. Namun fungsi intermediasi bank belum optimal baik dari kemampuan dalam menghimpun dana maupun kualitas kredit yang disalurkan. Kualitas penyaluran kredit yang disalurkan masih mendominasi pangsa kredit komsumsi. Sedangkan untuk pertumbuhan kredit untuk kegiatan produktif yaitu kredit modal kerja dan investasi yang sifatnya jangka panjang tumbuh lebih rendah dibandingkan dengan kredit komsumsi. 
Sehingga jika melihat fenomena yang terjadi atas perbankan Indonesia dan kajian dari beberapa peneliti yang memiliki hasil yang berbeda, maka perlu dilakukan kajian mendalam mengenai karakteristik spesifik bank yang ditinjau lebih luas dari tipe kepemilikan bank di Indonesia yaitu bank pemerintah, domestik, campuran, dan bank asing. Mengingat dari beberapa hasil penelitian menunjukkan bahwa struktur kepemilikan dan karakteristik spesifik bank memiliki pengaruh terhadap struktur modal (Darwanto, 2008, Gropp \& Heider, 2009). Namun dalam proses pemilihan sumber pendanaan bank untuk meningkatkan pertumbuhan penyaluran kredit masih terdapat perbedaan apakah dengan meningkatkan ekuitas (Kishan dan Opiela, 2000, Darwanto, 2008) atau dengan penambahan utang (Inderst \& Mueller, 2008), dan ini memerlukan kajian lebih lanjut.

Pergeseran struktur kepemilikan bank kemungkinan berpengaruh terhadap keputusan keuangan (financing decision) yang diambil dalam perusahaan termasuk kebijakan struktur modal bank dan juga pelaksanaan fungsi intermediasi bank yaitu dalam proses penyaluran kredit. Secara spesifik tujuan paper ini, pertama, adalah menganalisis seberapa besar pengaruh struktur kepemilikan bank dominasi pemerintah, domestik, asing, profitabilitas, ukuran bank (size), resiko kredit dan beban manajemen secara simultan terhadap struktur modal bank. Kedua, menganalisis seberapa besar pengaruh struktur kepemilikan bank dominasi pemerintah, domestik, asing,profitabilitas, ukuran bank (size), resiko kredit dan beban manajemen secara parsial terhadap Struktur Modal Bank. Ketiga, menganalisisseberapa besar pengaruh simultan Struktur Kepemilikan (bank dominasi pemerintah, domestik, asing), karakteristik spesifik bank (profitabilitas, ukuran bank (size), resiko kredit dan beban manajemen) dan struktur modal bank terhadap pelaksanaan fungsi intermediasi bank.

Bagian kedua dari paper ini mengulas teori dan studi literatur, bagian ketiga mengulas metodologi dan data yang digunakan sementara bagian keempat mengulas hasil estimasi dan analisis. Kesimpulan dan implikasi kebijakan diberikan pada bagian penutup.

\section{TEORI}

Bank merupakan bisnis yang menawarkan simpanan, yang dapat melaksanakan permintaan penarikan (dengan menggunakan cek atau membuat transfer dana elektronik) dan menyalurkannya dalam bentuk kredit yang bersifat komersial (Rose dan Hudgins, 2010). Apostolik et.al (2009) membagi kegiatan inti bank atas 3 kegiatan inti yaitu (1) deposit collection, yaitu proses penghimpunan dana dari masyarakat berupa giro, tabungan dan deposito berjangka (2) payment services, memberikan jasa keuangan yaitu lalu lintas pembayaran, proses transfer uang (3) loan underwriting, menyalurkan dana ke masyarakat dalam bentuk kredit.

Fungsi utama dari perbankan adalah intermediasi keuangan, yakni proses pembelian surplus dana dari sektor usaha, pemerintah maupun rumah tangga, untuk disalurkan kepada unit ekonomi yang defisit. Fungsi intermediasi keuangan muncul sebagai akibat dari mahalnya 
biaya monitoring, biaya likuiditas dan risiko harga (price risk) karena adanya informasi asymetric antara pemilik dana (household/net savers) dengan perusahaan pengguna dana (corporations/ netborrowers) sehingga dibutuhkan pihak perantara (intermediary) yang mampu mengakomodir kebutuhan kedua belah pihak (Saunders, 2008). Lebih lanjut, Saunders (2008) mengemukakan bahwa fungsi dan peranan intermediasi keuangan yaitu: (1) function as broker, (2) function as asset transformers, (3) roleas delegated monitor, (4) role as information producer.

Fungsi intermediasi perbankan telah mengalami perubahan akibat adanya perubahan lingkungan ekonomi dan perkembangan pasar keuangan terutama terjadi dinegara-negara maju (industrialized countries) seperti negara-negara di Uni Eropa (Bikker \& Wesseling, 2003). Perkembangan teknologi informasi, deregulasi, liberalisasi, internasionalisasi menjadi faktor penyebab teori intermediasi keuangan menjadi tidak relevan dengan praktik bisnis yang terjadi sekarang (Scholtens \& Wensveen, 2003). Faktor-faktor tersebut cenderung untuk mengurangi biaya transaksi (transaction-cost) dan informasi asymetris antara penabung (savers) dengan investor dan hal ini bertentangan dengan fungsi intermediasi keuangan klasik.

Bikker \& Wesseling (2003) juga menyatakan bahwa liberalisasi dan perkembangan teknologi informasi dipasar modal telah menyebabkan fungsi intermediasi beralih dari bank ke pasar modal dan lembaga keuangan non-intermediary seperti asuransi. Liberalisasi lembaga keuangan non-bank yaitu terlihat dalam proses memfasilitasi masyarakat untuk menyimpan asset dan melakukan investasi. Dan liberalisasi masyarakat melalui kebebasan dalam memilih sarana untuk menyimpan asset. Selain itu perkembangan teknologi telah membantu masyarakat dalam memonitor perkembangan asset mereka dan memberi peluang untuk melakukan diversifikasi atas asset yang dimiliki, sehingga mengurangi monitoring-cost. Hal ini yang menyebabkan terjadinya disintermediation dalam industri perbankan.

Globalisasi dan tingkat persaingan yang terjadi antara lembaga perbankan dan pasar modal juga mempengaruhi aktivitas intermediasi perbankan (banking business activity). Hal tersebut menyebabkan terjadinya peningkatan konsolidasi perbankan melalui merger dan akuisisi, dengan tujuan untuk meningkatkan skala kapasitas melalui peningkatan asset (Bikker \&Wesseling, 2003). Konsolidasi bank tersebut menyebabkan terjadinya peningkatan kepemilikan bank oleh asing (foreign-owned bank), hal ini ini bukan saja terjadi pada negara-negara maju (industrialized countries) (Bikker \& Wesseling, 2003), tetapi juga pada negara-negara berkembang (emerging countries) (Mian, 2003).

Fungsi intermediasi dapat dilaksanakan dengan optimal jika didukung permodalan yang memadai (Buchory, 2006). Karena meskipun dana pihak ketiga yang dihimpun sangat besar namun apabila tidak diimbangi oleh tambahan modal maka bank akan terbatas dalam menyalurkan kreditnya. Senada dengan hasil penelitian Kishan dan Opiela (2000) menemukan bahwa pertumbuhan penyaluran kredit dipengaruhi oleh ukuran bank (asset) dan modal bank (leverage ratio) yaitu dengan penambahan ekuitas (modal sendiri). Berbeda dengan Inderst \& Mueller (2008), hasil penelitian menunjukkan bahwa dengan asumsi tanpa adanya regulasi, 
leverage memiliki korelasi yang positif terhadap tingkat pemberian kredit yang beresiko. Atau dengan kata lain, penambahan modal melalui utang akan berpengaruh terhadap peningkatan penyaluran kredit.

\subsection{Konsep Struktur Modal}

Struktur modal merupakan salah satu bagian yang sangat penting dalam proses pengambilan keputusan keuangan, karena memiliki hubungan timbal balik terhadap keputusan variabel-variabel keuangan lainnya. Brigham (2005:547) mengemukan pengertian struktur modal yaitu:

"The firm's mixture of debt and equity is called its capital structure. The capital structure decisions include a firm's choice of target capital structure, the average maturity of its debt, and the specific sources of financing it chooses at any particular time. Managers should make capital structure decisions designed to maximize the firm's value".

Oleh karena struktur modal menggambarkan proporsi antara modal yang dimiliki oleh suatu perusahaan yang berasal dari hutang jangka panjang (long-term debt) dan modal sendiri (equity), sehingga struktur modal dalam penelitian ini akan diukur dengan Debt to Equity Ratio (DER) yaitu perbandingan antara total utang (debt or liability) terhadap total modal sendiri (equity). Semakin tinggi DER menunjukkan komposisi total hutang semakin besar dibanding dengan total modal sendiri (ekuitas) dan sebaliknya.

Landasan berpikir yang digunakan untuk mengetahui struktur modal optimal yaitu melalui teori struktur modal yang terdiri dari: (a) Modigliani-Miller (MM) Theory yaitu apabila pajak tidak diperhitungkan, MM berpendapat bahwa nilai perusahaan tidak terpengaruh oleh struktur modal, (b) Trade-Off Theory, menjelaskan bahwa perusahaan akan memiliki struktur modal yang optimal berdasarkan adanya keseimbangan (trade-off) antara manfaat (benefit) dan biaya (costs) yang diperoleh dari penggunaan utang (c) Pecking Order Theory, menjelaskan bahwa perusahaan akan menentukan hirarki dari sumber pendanaannya dimana pendanaan dari dalam perusahaan (internal financing) lebih didahulukan dari pada sumber pendanaan dari luar perusahaan (external financing). Teori ini bukan saja berlaku pada perusahaan non-keuangan tetapi juga berlaku terhadap industri perbankan (Marques \& Santos, 2003). Marques dan Santos (2003) mengatakan bahwa dalam proses pengambilan keputusan struktur modal yang terutama diperhatikan adalah trade-off antara insentif dengan tata kelola (governance), serta struktur kepemilikan bank sebagai kontrol terhadap pengalokasian ekuitas dan utang (equity/debt).

Jika dihubungkan dengan pelaksanaan fungsi intermediasi bank, maka bank seharusnya meningkatkan sumber dana dari modal sendiri (ekuitas) karena memiliki tingkat volatilitas yang 
rendah dan biayanya yang murah dibandingkan dengan utang. Hal ini sesuai dengan pendapat Buchory (2006) dan Kishan dan Opiela (2000). Selain itu dalam kondisi perbankan Indonesia dibawah regulasi yang ketat, bank disarankan untuk tidak mengambil resiko yang tinggi dengan menambah utang untuk kredit beresiko tinggi, mengingat resiko kredit dan resiko kebangkrutan yang akan dihadapi dapat mengurangi tingkat kepercayaan masyarakat terhadap bank. Hal ini bertentangan dengan pendapat Inderst \& Mueller (2008). Sehingga diperkirakan bahwa struktur modal bank berpengaruh positif terhadap fungsi intermediasi bank, terutama dalam penyaluran kredit.

\subsection{Struktur Kepemilikan}

Keputusan penentuan struktur modal merupakan kebijakan yang diambil oleh manajemen perusahaan yang dipengaruhi oleh pemilik atau pemegang saham. Struktur kepemilikan mewakili sumber kekuasaan (source of power) yang dapat digunakan untuk mengendalikan atau mengontrol manajemen perusahaan terutama dalam proses pengambilan keputusan atau kebijakan-kebijakan dalam perusahaan. Relevansi struktur kepemilikan terhadap struktur modal dapat dijelaskan melalui Agency Cost Theory, yang menyatakan bahwa manajer dan pemilik (pemegang saham) memiliki hubungan keagenan. Hubungan keagenan yaitu kontrak antara seseorang atau lebih sebagai principal yang memberikan otoritas kepada seseorang (agent) untuk membuat beberapa keputusan atas nama principal yang tujuannya untuk memaksimalkan keuntungan bagi pemegang saham (principal). Konflik kepentingan dan konsekuensi dari kontrak diatas pada akhirnya akan menimbulkan adanya agency cost atau biaya keagenan.

Hubungan keagenan pada lembaga perbankan sangat kompleks, karena akan melibatkan hubungan pemegang saham dengan manajemen (agen), hubungan bank dengan debitur, juga melibatkan hubungan bank dengan regulator (Taswan, 2010). Dalam perspektif manajemen perbankan, hutang menjadi sumber dana utama bagi bank yang berasal dari sumber dana pihak ketiga (DPK), dengan demikian peran hutang bagi bank sangat besar. Penggunaan hutang dari dana masyarakat menjadi alat insentif bagi manajer untuk bekerja lebih berhati-hati guna menghindari ancaman risiko kebangkrutan dan untuk menjaga kepercayaan masyarakat terhadap bank tersebut.

Taswan (2010) berdasarkan kajian empiris yang dilakukan oleh Atif Mian (2003) membagi struktur kepemilikan bank di Indonesia menjadi 4 yaitu kepemilikan terkonsentrasi, kepemilikan pemerintah, domestik dan kepemilikan asing. Dalam paper ini, struktur kepemilikan dominasi pemerintah maupun swasta, dihipotesiskan akan berpengaruh positif signifikan terhadap struktur modal (DER). Ini berarti, bagi perbankan yang dikuasai pemerintah atau swasta domestik, dalam struktur modalnya akan cenderung meningkatkan hutang relatif terhadap modal sendiri. Hal sebaliknya, struktur kepemilikan asing berpengaruh negatif signifikan terhadap besaran DER. 


\subsection{Karakteristik Spesifik Bank}

Karakteristik spesifik bank merupakan faktor-faktor yang berasal dari kondisi internal perusahaan(the firm internal condition) atau bank yang mempengaruhi terhadap kebijakan struktur modal, yang dapat dilihat dari neraca dan laporan laba rugi bank (Athanasoglou et.al, 2005). Dalam penelitian ini akan digunakan 4 faktor utama dari karakteristik spesifik bank untuk menentukan kebijakan struktur modal yaitu: (1) profitabilitas, (2) ukuran bank (size), (3) resiko kredit dan (4) beban manajemen.

Profitabilitas merupakan tingkat kemampuan bank untuk menghasilkan laba selama periode tertentu yang dinyatakan dalam persentase. Tingkat profitabilitas perbankan biasanya dihitung dengan menggunakan rasio ROA (return on asset) yaitu perbandingan antara net income dengan total asset. ROA mencerminkan kemampuan manajemen bank untuk menghasilkan keuntungan dari asset bank (Athanasoglou. et.al, 2005). Dengan demikian, hopotesis yang dibangun adalah profitabilitas berpengaruh negatif signifikan terhadap struktur modal bank.

Size atau ukuran menunjukkan skala usaha yang dilakukan oleh perusahaan. Size atau ukuran perusahaan terlihat dari dari jumlah aset atau aktiva perusahaan, bertambahnya aktiva perusahaan menunjukkan bertambah besar investasi yang dilakukan. Ukuran bank (size) dihipotesiskan akan memiliki pengaruh positif signifikan terhadap struktur modal bank.

Risiko Kredit atau disebut dengan default risk yaitu merupakan suatu risiko akibat kegagalan atau ketidakmampuan nasabah mengembalikan jumlah pinjaman yang diterima dari bank beserta bunganya sesuai dengan jangka waktu yang ditentukan (Dahlan Siamat, 1999). Dengan demikian, hipotesis yang dapat dibangun adalah bahwa resiko kredit berpengaruh negatif signifikan terhadap struktur modal bank.

Beban manajemen (expense management) mencerminkan total beban biaya yang dikeluarkan oleh manajemen dalam menjalankan usahanya yaitu operating cost dan biaya beban lainnya (other expense). Peningkatan beban manajemen, yang diproksi dengan proporsi relatif antara total biaya terhadap total aktiva perusahaan, akan memiliki hubungan searah dengan leverage bank. Dalam paper ini, peningkatan beban manajemen bank berpengaruh positif signifikan terhadap struktur modal bank, yakni dalam bentuk peningkatan total hutang relatif terhadap modal sendiri (ekuitas).

Banyak penelitian yang dilakukan mengenai pengaruh specifik bank terhadap struktur modal dengan hasil yang berbeda-beda. Gropp dan Heider (2009) \& Titman dan Wessels (1988) menemukan bahwa profitability memiliki pengaruh yang negatif terhadap kebijakan utang, dan size berpengaruh positif terhadap kebijakan utang. Sedangkan risiko kredit berpengaruh negatif terhadap kebijakan utang (Darwanto, 2008 \& Gropp dan Heider, 2009) dan beban manajemen memiliki pengaruh positif terhadap kebijakan utang (Titman \& Wessel, 1998 \& Darwanto, 2008). 


\section{METODOLOGI}

Metode penelitian yang digunakan adalah dengan pendekatan analisis deskriptif karena dilakukan untuk memperlihatkan dan menguraikan keadaan obyek penelitian dan dilanjutkan dengan analisis verifikatif karena dilakukan pengujian untuk mencari kebenaran dari suatu hipotesis.Sedangkan analisis dilakukan melalui pendekatan kuantitatif dengan menggunakan metode statistik untuk menguji hipotesis.

Dalam penelitian ini penulis menggunakan variabel independen yaitu struktur kepemilikan yang dibagi 3 berdasarkan proporsi kepemilikan saham terbesar dan mayoritas (large block shareholding) dengan tipe kepemilikan yakni kepemilikan pemerintah, domestik, asing. Kemudian karakteristik spesifik bank yang terdiri dari profitabilitas, ukuran bank (size), risiko kredit, dan beban manajemen. Sedangkan untuk variabel dependen terdiri dari variabel struktur modal sebagai variabel intervening dan fungsi intermediasi bank.

\subsection{Model Empiris}

Berdasarkan model dalam kerangka penelitian dimana terdapat dua variabel dependen yang salah satunya adalah variabel intervening yaitu variabel struktur modal (DER), maka analisis yang digunakan dalam penelitian ini adalah analisis jalur (path analysis). Struktur model antar variabel dalam penelitian ini dapat ditunjukkan pada gambar 1 sebagai berikut:

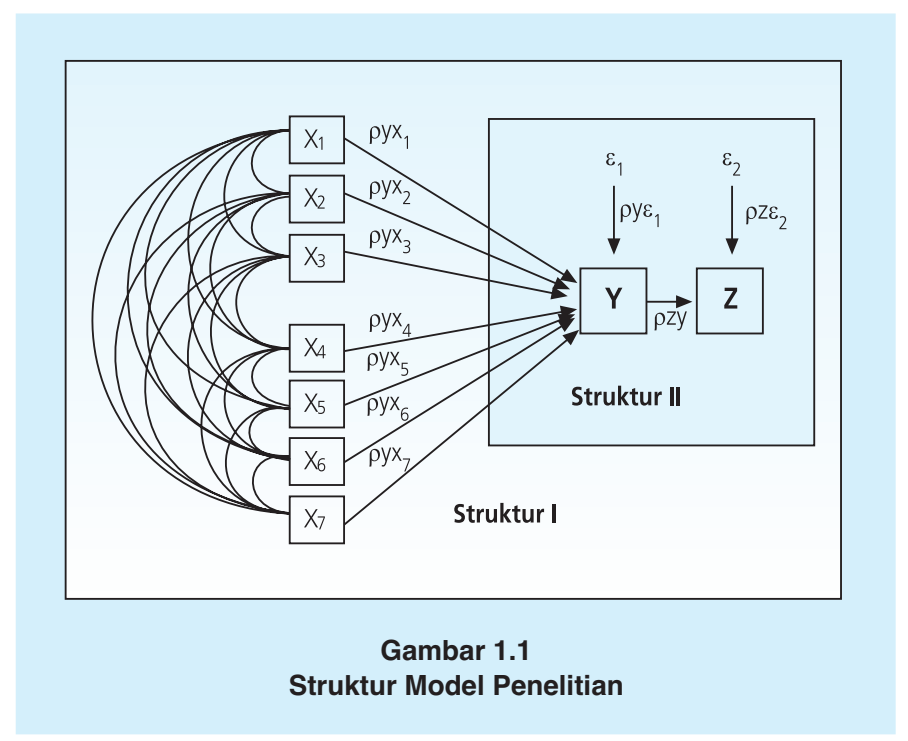

Dari gambar struktur model tersebut diatas, maka persamaan struktural yang dibuat dibagi dalam dua struktur dengan persamaan sebagai berikut : 


\section{Persamaan Struktur 1 :}

$$
Y=\rho y x_{1} X_{1}+\rho y x_{2} X_{2}+\rho y x_{3} X_{3}+\ldots . .+\rho y x_{7} X_{7}+\rho y \varepsilon_{1}
$$

\section{Persamaan Struktur 2 :}

$$
Z=\rho y x_{1} X_{1}+\rho y x_{2} X_{2}+\rho y x_{3} X_{3}+\ldots . .+\rho y x_{7} X_{7}+\rho z y+\rho z \varepsilon_{2}
$$

Persamaan diatas digunakan untuk menjelaskan pengaruh langsung variabel exogenous terhadap variabel endogenous yang terdapat dalam model. Model persamaan $Y$ adalah model mengenai pembentukan Struktur Modal yang dipengaruhi oleh Struktur Kepemilikan $\left(\mathrm{X}_{1}, \mathrm{X}_{2}, \mathrm{X}_{3}\right)$ dan Karakteristik spesifik Bank $\left(\mathrm{X}_{4} \mathrm{X}_{5}, \mathrm{X}_{6}, \mathrm{X}_{7}\right)$. Sedangkan model persamaan Z adalah model mengenai pembentukan Fungsi Intermediasi Bank yang dipengaruhi oleh Struktur Kepemilikan, Karakteristik spesifik Bank, dan Struktur Modal (Y).

\subsection{Data}

Unit analisis adalah bank umum konvensional di Indonesia dengan periode pengamatan 2006-2009. Dimana penarikan sampel dilakukan dengan purposive sampling sehingga diperoleh total sampel sebesar 54 bank dari total 121 bank. Metode analisis data yang digunakan dalam penelitian ini adalah analisis jalur (path analysis).

Pada penelitian ini, bank yang dijadikan sampel adalah bank umum konvensional yang memiliki struktur kepemilikan mayoritas dipegang oleh satu pemegang saham yaitu kepemilikan $\geq 51 \%$ dari total saham berturut-turut selama periode pengamatan yaitu tahun 2006-2009. Dari keseluruhan populasi Bank Umum Konvensional hanya 54 bank yang memenuhi kriteria untuk dijadikan sampel yang terdiri dari 12 bank pemerintah (BUMN dan BPD), 24 Bank Swasta Domestik (BUSN Devisa dan Non Devisa), dan 18 Bank Asing (Bank Campuran dan Asing). Beberapa sampel digugurkan karena tidak memenuhi kriteria yang telah ditetapkan dan datanya tidak lengkap.

Terkait dengan data maka perlu dilakukan uji normalitas yang bertujuan untuk menguji apakah dalam model regresi, variabel pengganggu atau residual memiliki distribusi normal. Pada penelitian ini, uji normalitas yang digunakan yaitu dengan analisis grafik plot dan uji Kolmogorov-Smirnov, karena sampel yang digunakan cukup besar. Hasil uji Normalitas pengolahan data dalam penelitian ini dibagi dua, karena struktur persamaan analisis jalurnya terbagi 2 yaitu uji normalitas persamaan struktur 1 dan persamaan struktur 2 .

Dari hasil uji grafik baik struktur persamaan 1 dan 2 menunjukkan bahwa terlihat titiktitik menyebar disekitar garis diagonal, serta penyebarannya agak menjauh dari garis diagonal. Hal ini menunjukkan bahwa data residual tidak berdistribusi normal. Sama halnya pengujian 
dengan uji Kolmogorov-Smirnov diperoleh hasil probabilitas persamaan struktur $1(0,013<0,05)$ dan probabilitas persamaan struktur $2(0,000<0,05)$, dengan demikian data residualnya juga tidak berdistribusi normal.

Hasil ini berdampak pada perlunya dilakukan pengurangan data atau pengeluaran (outlier) terhadap data-data variabel yang memiliki nilai ekstrem atau memiliki penyimpangan yang sangat besar, agar hasil pengujian terhadap pengolahan datanya valid. Dari hasil identifikasi diperoleh beberapa sampel bank memiliki nilai penyimpangan yang cukup besar dibandingkan dengan bank yang lain.Sejumlah 6 (enam) sampel bankdikeluarkan dari tabulasi data yaitu PT Bank Akita/Bank Barclay Indonesia, PT Bank BNP Paribas, PT Bank Maybank, PT Rabobank, Bank Of China Limited, The Bangkok Bank Comp.Ltd, sehingga jumlah sampel yang diuji menjadi 48 bank. Hasil pengujian normalitas untuk persamaan struktur 1 dan 2 dengan uji grafik plot terlihat bahwa data menyebar disekitar garis diagonal dan mengikuti arah garis diagonal tersebut. Hal ini menunjukkan bahwa data residual berdistribusi normal. Demikian halnya dengan pengujian dengan Kolmogorov-Smirnov, probabilitas untuk persamaan struktur 1 adalah sebesar 0,194>0,05, dan probabilitas untuk persamaan struktur 2 adalah sebesar 0,116>0,05. Artinya bahwa data residual untuk persamaan struktur II juga berdistribusi normal. Oleh karena uji normalitas kedua persamaan struktur diatas telah menunjukkan bahwa data residual berdistribusi normal atau tidak menyalahi asumsi normalitas, maka pengolahan data selanjutnya dapat dilakukan.

Selain uji normalitas di atas, hal penting lain yang perlu dilakukan adalah memastikan agar model yang diestimasi terbebas dari masalah multicollinearity, yang dapat dideteksi dari hubungan antar variabel independent. Hubungan atau korelasi menunjukkan indikasi awal adanya hubungan antar variabel penjelas (eksogenous). Untuk menguji hubungan diantara variabel-variabel eksogenuos maka dilakukan perhitungan nilai koefisien korelasi terhadap masing-masing variabel struktur kepemilikan dan karakteristik spesifik bank.

Dari hasil perhitungan korelasi antar variabel eksogen dengan menggunakan SPSS 18.0 diperoleh nilai korelasi yang bernilai negatif dan positif, dimana nilai tersebut hanya menujukkan arah hubungan antar variabel. Nilai negatif menunjukan hubungan yang berlawanan, sedangkan nilai negatif menunjukkan hubungan yang searah.

Nilai korelasi yang sangat kuat namun bernilai negatif yaitu korelasi antara kepemilikan domestik dengan size (ukuran bank) yaitu sebesar (-0.608) dan signifikan pada $\alpha=0,01$. Artinya bahwa kepemilikan domestik memiliki hubungan negatif dengan size atau semakin besar proporsi kepemilikan domestik atas bank maka size (total assetnya) biasanya kecil, dan sebaliknya. Sedangkan korelasi yang sangat rendah terdapat pada korelasi antara ROA dengan NPL yakni sebesar 0,003 dan tidak signifikan (korelasi ini bisa dianggap tidak ada atau diabaikan karena nilainya sangat kecil).

Untuk korelasi yang cukup kuat dan signifikan terdapat pada korelasi variabel struktur kepemilikan yaitu korelasi kepemilikan pemerintah dengan kepemilikan domestik sebesar 
$(-0,454)$ yang artinya bahwa jika proporsi kepemilikan pemerintah bertambah sebesar 45,4\% maka proporsi kepemilikan domestik akan berkurang sebesar 45,4\%, demikian sebaliknya. Selain itu korelasi yang cukup kuat ditunjukkan oleh kepemilikan pemerintah dengan asing yaitu sebesar $(-0,460)$, dan Kepemilikan Domestik dan Asing yaitu sebesar $(-0,522)$. Korelasi yang cukup kuat ini terjadi karena ketiga variabel tersebut merupakan bagian dari konsep struktur kepemilikan yang memiliki hubungan (korelasi) yang berlawanan satu sama lain. Sedangkan untuk korelasi variabel-variabel lainnya memiliki korelasi yang rendah.

\section{HASIL DAN ANALISIS}

\subsection{Analisis Deskriptif}

Rata-rata nilai rasio DER diperoleh rasio tertinggi yaitu sebesar 1753,83\% dimiliki oleh Bank of China Limited, dan rasio terendah yaitu sebesar 11,51\% dimiliki oleh PT. Maybank IndoCorp., dengan total rata-rata rasio DER sebesar 500,79\%. Nilai rasio DER yang cukup besar disebabkan oleh tingkat hutang yang besar yang berasal dari tabungan dan deposito atau disebut sebagai sumber dana pihak ketiga, hal ini berkaitan dengan fungsi utama bank sebagai penghimpun dana dari masyarakat. Sedangkan rata-rata nilai ekuitas yang cukup besarterdapat pada bank yang sudah go public (listed) karena bank-bank tersebut selain mendapatkan tambahan modal dari pemilik juga dari masyarakat melalui pasar modal.

Rata-rata rasio Loan to Deposit Ratio (LDR) yang paling tinggi yaitu sebesar 320,89\% dimiliki oleh The Bangkok Bank Comp.Ltd, dan yang paling rendah sebesar 21,09\% dimiliki oleh Bank China of Limited, dengan rata-rata rasio LDR seluruh bank sampel yaitu sebesar $88,67 \%$. Rata-rata Rasio LDR ini cukup baik, karena 88,67\% dari total dana pihak ketiga yang dihimpun dari masyarakat disalurkan dalam bentuk kredit, sehingga dapat dikatakan bahwa fungsi intermediasi dari bank sampel berjalan dengan baik. Rata-rata nilai rasio LDR yang besar dimiliki oleh bank asing, hal disebabkan karena pada umumnya bank asing mendapatkakn bantuan likuiditas dari kantor pusat (perusahaan induk) di luar negeri.

Selama periode tahun 2006-2009 terjadi pergeseran struktur kepemilikan pada beberapa bank domestik, menjadi kepemilikaan mayoritas oleh asing, sedangkan untuk struktur kepemilikan pemerintah tetap. Setelah dilakukan pengelompokan data, diperoleh total ratarata ROA tertinggi terdapat pada bank kepemilikan asing yaitu sebesar 3,11\%, kemudian bank kepemilikan pemerintah sebesar 2,89\% dan yang terendah bank domestik yaitu sebesar 1,76\%. Rata-rata ROA bank kepemilikan domestik berada dibawah nilai ROA standar yang ditetapkan oleh bank Indonesia yaitu ROA>2\%. Untuk rata-rata nilai Asset terbesar dimiliki oleh bank kepemilikan pemerintah yaitu sebesar 16,69 (dalam logaritma natural), kemudianbank kepemilikan asing sebesar 16,00 (dalam logaritma natural) dan rata-rata terendah dimiliki oleh bank kepemilikan domestik. Total nilai asset bank kepemilikan pemerintah didominasi oleh bank BUMN yaitu PT Bank Mandiri, PT Bank Rakyat Indonesia dan PT Bank Negara Indonesia. 
Sedangkan nilai asset pada bank kepemilikan asing didominasi oleh PT Bank Danamon, PT Bank CIMB Niaga, PT Bank Internasional Indonesia dan Citi Bank N.A.

Untuk rata-rata nilai rasio risiko kredit (NPL), nilai rata-rata NPL terbesar dimiliki oleh bank kepemilikan pemerintah yaitu sebesar 3,86\%, kemudian bank kepemilikan asing sebesar $3,32 \%$ dan yang terendah adalah bank kepemilikan domestik yaitu sebesar 2,66\%. Berbeda dengan nilai beban manajemen (EM), rata-rata beban manajemen terbesar terdapat pada bank kepemilikan domestik yaitu sebesar 10,23\%, kemudian bank pemerintah sebesar 9,20\% dan terendah terdapat pada bank kepemilikan asing sebesar 7,49\%. Hal ini menunjukkan bahwa bank domestik dan bank pemerintah di Indonesia masih belum efisien, dibandingkan dengan bank kepemilikan asing.

Demikian halnya dengan nilai rata-rata DER, nilai terbesar dimiliki oleh bank domestik yakni sebesar 589,64\%, kemudian bank pemerintah sebesar 560,38\% dan nilai terendah dimiliki oleh bank kepemilikan asing yakni sebesar 400,80\%. Hal ini menunjukkan bahwa bank domestik dan pemerintah lebih dominan menggunakan utang dari pada ekuitas dalam struktur modalnya. Sedangkan untuk nilai rata-rata Loan to Deposit Ratio (LDR), nilai terbesar dimiliki oleh bank kepemilikan asing yaitu sebesar 107,24\%, kemudian bank domestik sebesar 79,07\% dan terendah dimiliki oleh bank pemerintah yaitu sebesar 65,35\%. Rata-rata nilai rasio LDR yang besar (>100\%) didominasi oleh bank asing dan bank campuran, sedangkan untuk nilai LDR $(<100 \%)$ dimiliki oleh bank domestik dan bank pemerintah.

\subsection{Hasil Analisis Jalur untuk Persamaan Struktur I}

Persamaan struktur I dalam model penelitian ini adalah untuk mengetahui dan menguji besar pengaruh struktur kepemilikan bank (kepemilikan pemerintah, domestik, asing) dan karakteristik spesifik bank (profitabilitas, ukuran bank (size), resiko kredit dan beban manajemen) secara simultan terhadap struktur modal.

Hasil estimasi memiliki koefisien determinasi $\left(R^{2}\right)$ sebesar 0,496 atau 49,6\%. Nilai ini memiliki arti bahwa variabilitas struktur modal (DER) yang dapat dijelaskan dengan menggunakan variabel struktur kepemilikan pemerintah, domestik, asing, profitabilitas, ukuran bank (size), resiko kredit dan beban manajemen adalah sebesar 49,6\%, sedangkan sisanya sebesar 50,4\% dipengaruhi oleh faktor-faktor lain diluar model ini. Meski besaran koefisien determinasi ini kecil, uji F menunjukkan adanya pengaruh simultan dari struktur kepemilikan pemerintah, domestik, asing, profitabilitas, ukuran bank (size), resiko kredit dan beban manajementerhadap struktur modal.

Sedangkan secara parsial pengaruh dari ketujuh variabel eksogenous terhadap struktur modal dijelaskan dengan melihat arah, nilai dan signifikansi masing-masing koefisien jalur dari variabel eksogenous. 


\subsubsection{Pengaruh Struktur Kepemilikan Pemerintah, Domestik Swasta dan Asing terhadap Struktur Modal}

Secara statistik struktur kepemilikan pemerintah berpengaruh signifikan negatif terhadap struktur modal Hasilini tidak konsisten dengan hipotesis awal yakni struktur kepemilikan pemerintah berpengaruh positif terhadap struktur modal.

Jika melihat pengaruh langsung struktur kepemilikan pemerintah terhadap struktur modal yaitu sebesar 15,37\%, memiliki arah yang sama. Namun jika dihubungkan dengan variabel eksogen lainnya pengaruh tersebut menjadi berkurang dan bernilai negatif. Besarnya pengaruh total struktur kepemilikan pemerintah terhadap struktur modal menjadi sebesar $4,11 \%$. Hasil ini mengindikasikan bahwa bank dengan kepemilikan mayoritas pemerintah cenderung menggurangi hutang dalam menentukan sumber pendanaannya, atau dengan kata lain bank dengan kepemilikan pemerintah cenderung menggunakan ekuitas sebagai sumber pendanaannya. Hasil ini bertentangan dengan hasil penelitian Atif Mian (2003) yang menyatakan bahwa bank kepemilikan pemerintah, memiliki kontrol yang lemah karena dalam bank pemerintah prinsip yang berlaku adalah agen dengan agen, bukan agen dengan principal sehingga cenderung menggunakan utang sebagai kontrol untuk mengurangi konflik keagenan. Dan juga pendapat Smith (2005), yaitu bahwa kepemilikan ekuitas yang terkonsentrasi memiliki hubungan yang kuat dengan pemegang hutang yang terkonsentrasi.

Hasil pengujian parsial menunjukkan struktur kepemilikan domestik secara signifikan berpengaruh negatif terhadap struktur modal. Namun demikian arah hubungan variabelnya tidak konsisten dengan prediksi peneliti pada saat awal perumusan hipotesis.

Sama halnya dengan struktur kepemilikan pemerintah, bank dengan kepemilikan domestik cenderung menggurangi hutang dalam menentukan sumber pendanaannya, atau dengan kata lain bank dengan kepemilikan domestik cenderung menggunakan ekuitas sebagai sumber pendanaannya. Jika melihat pengaruh langsung struktur kepemilikan domestik terhadap struktur modal pada awalnya bernilai searah (positif) yaitu sebesar 10,69\%, namun karena adanya hubungan/korelasi dengan variabel lainnya sehingga pengaruh total kepemilikan domestik terhadap struktur modal menjadi bernilai negatif yaitu sebesar $-3,85 \%$. Dan hal ini juga bertentangan dengan hasil penelitian Atif Mian (2003) yang menyatakan bahwa kepemilikan bank domestik cenderung menggunakan hutang dalam struktur modal bank dan juga bertentangan dengan pendapat Smith (2005).

Hasil pengujian parsial menunjukkan struktur kepemilikan asing berpengaruh negatif signifikan terhadap struktur modal bank, dengan total pengaruh sebesar $15,83 \%$. Artinya bahwa bank dengan kepemilikan asing, cenderung mengurangi hutang atau lebih cenderung menggunakan ekuitas dalam struktur modalnya. Hasil ini sejalan dengan hasil penelitian Atif Mian (2003) dan Douma \& Kabir (2002) yang mengemukakan bahwa bank dengan kepemilikan asing, cenderung moderat dalam menyusun portofolionya, karena memiliki pengawasan/kontrol yang ketat dari perusahaan induk dan bank kepemilikan asing biasanya 
memiliki likuiditas yang relatif lebih besar yang diperoleh dari perusahaan induk dan memiliki rasio modal yang cukup besar. Atif Mian (2003) juga menyatakan bahwa bank swasta asing cenderung menggunakan ekuitas yang tujuannya untuk meng-cover risiko.

Jika dilihat dari komposisi struktur kepemilikan dari 54 bank sampel dengan periode pengamatan tahun 2006-2009, nilai maksimum kepemilikan bank oleh pemerintah dan asing adalah 100\%, dan kepemilikan domestik sebesar 99,998\%. Sedangkan kepemilikan saham minimum baik oleh pemerintah, domestik, maupun asing sebesar 0\%. Kepemilikan saham 100\% oleh pemerintah yaitu terdapat pada PT Bank Tabungan Negara (Persero) sahamnya sepenuhnya dimiliki oleh Pemerintah Pusat, sedangkan 100\% kepemilikan Asing terdapat pada bank asing yang berstatus sebagai kantor cabang yaitu Bank of China Limited, Citi Bank N.A, Deutsche Bank AG, The Bangkok Bank Comp. Ltd, dan The Bank of Tokyo Mitsubishi.

Untuk rata-rata kepemilikan saham oleh pemerintah sebesar 71,27\%, kepemilikan domestik sebesar 41,95\%, dan kepemilikan asing rata-rata sebesar 82,12\%. Selama tahun 2006-2009 terjadi pergeseran struktur kepemilikan bank, dimana kepemilikan bank oleh domestik menjadi kepemilikan bank oleh asing, sedangkan jumlah kepemilikan bank oleh pemerintah tetap. Beberapa bank yang masuk kategori Bank Umum Swasta Domestik (BUSD) Devisa mengalami pergeseran kepemilikan mayoritas pihak asing pada tahun 2007 yaitu PT Bank Niaga berubah menjadi PT Bank CIMB Niaga, PT Bank Bumi Putera Indonesia berubah menjadi PT Bank ICB Bumi Putera Indonesia, dan PT Bank Nusantara Parahyangan. Selain itu Bank Akita juga pada tahun 2009 kepemilikan mayoritas bergeser kepada pihak asing sehingga berubah nama menjadi PT Bank Barclay Indonesia. Sedangkan bank domestik yang kepemilikan sahamnya mayoritas dimiliki oleh asing selama periode 2006-2009 yaitu PT Bank Danamon, PT Bank Internasional Indonesia, PT Bank OCBC NISP, dan PT Bank UOB Buana.

\subsubsection{Pengaruh Profitabilitas Terhadap Struktur Modal}

Dari 216 rasio ROA, yang paling besar adalah sebesar 11,12\% dan yang paling rendah sebesar $-22,76 \%$, sedangkan rata-ratanya (mean) sebesar 2,63\%. Ketentuan Bank Indonesia menetapkan bahwa rasio ROA yang baik atau sehat adalah sebesar $\geq 2 \%$. Secara umum ini menunjukkan bahwa perbankan mampu menghasilkan keuntungan dari asset yang dimiliki sebesar 2,63\% dan masuk kedalam kategori baik atau sehat. Pada lampiran 9, dari total 54 bank sampel, terdapat 4 bank yang memiliki ROA atau rasio keuntungan yang negatif, yaitu Bank Ganesha, Bank Harda Internasional, Bank Agroniaga dan Bank Akita, yang keseluruhannya termasuk dalam kategori bank swasta domestik. Sedangkan rata-rata ROA yang tinggi dimiliki oleh bank kepemilikan asing yang berstatus sebagai bank campuran seperti PT Bank BNP Paribas Indonesia (7,02\%), PT Bank China Trust Indonesia (6,07\%), PT Bank Woori Indonesia (5,92\%), PT Bank Maybank (5,74\%), dan PT Bank KEB Indonesia $(5,71 \%)$. 
Dari hasil pengujian parsial untuk $\mathrm{X}_{4}$ (Profitabilitas) menunjukkan bahwa profitabilitas berpengaruh negatifsignifikan terhadap struktur modal bank, dimana total pengaruhnya sebesar $24,72 \%$. Artinya bahwa semakin tinggi tingkat kemampuan bank menghasilkan laba dari assetnya (ROA) maka bank cenderung menurunkan atau mengurangi hutang sebagai sumber pendanaan. Hal ini sesuai dengan yang dikemukakan Myers (1984) bahwa tingkat profitabilitas yang tinggi akan membuat perusahaan menggunakan laba ditahan sebagai sumber dana dibandingkan dengan sumber dana dari luar yaitu dari hutang.

Hasil penelitian ini juga sejalan dengan hasil yang ditemukan oleh Gropp dan Heider (2009) yang menggunakan sampel bank-bank besar di Amerika. Selain itu Titman dan Wessels (1988) juga menemukan hasil yang sama pada perusahaan manufaktur. Jika dibandingkan dengan variabel karakteristik spesifik bank yang lainnya, tingkat profitabilitas memberikan pengaruh yang lebih besar terhadap struktur modal. Sedangkan untuk pengaruh tidak langsung, tingkat profitabilitas memberikan pengaruh tidak langsung yang cukup besar terhadap struktur modal jika dihubungkan dengan struktur kepemilikan asing yakni sebesar 6,87\%. Hal ini mengindikasikan bahwa profitabilitas yang cukup besar cenderung dimiliki oleh bank struktur kepemilikan asing dan menggunakan proporsi hutang yang lebih kecil karena kebutuhan dana dapat diperoleh dari laba ditahan (ekuitas).

\subsubsection{Pengaruh Size Terhadap Struktur Modal}

Size atau ukuran bank berpengaruh positif signifikan terhadap Struktur Modal Bank, dengan total pengaruh sebesar 7,61\%. Artinya bahwa semakin besar size (ukuran) bank maka semakin besar dalam menggunakan hutang sebagai sumber pendanaan. Hal ini sejalan dengan hasil penelitian Gropp dan Heider (2009), Darwanto (2008) yang menggunakan sampel bank dan juga oleh Titman dan Wessels (1988) pada perusahaan manufaktur.

Dari 216 pengamatan diperoleh nilai LnAsset terbesar yaitu 19,73 atau dalam nilai asset sebesar Rp 370.310.994 (dalam jutaan) dimiliki PT Bank Mandiri (Persero). Nilai Ln Asset terendah yaitu sebesar 11,22 atau dalam nilai asset sebesar Rp 74.251 (dalam jutaan) terdapat pada PT Bank Sahabat Purba Danarta. Sedangkan rata-rata (mean) LnAsset yaitu 15,55 atau dalam nilai asset sebesar Rp 25.676.935 (dalam jutaan). Sedangkandari rata-rata total asset selama periode tahun 2006-2009 yang dimiliki oleh 54 bank sampel, 3 nilai asset yang paling besar dimiliki oleh bank kepemilikan pemerintah yaitu bank BUMN (Persero) yang terdiri dari PT Bank Mandiri dengan rata-rata total asset sebesar Rp 317.090.587, PT Bank Rakyat Indonesia dengan ratarata total asset sebesar Rp 229.775.347 dan PT Bank Negara Indonesia dengan rata-rata total asset sebesar Rp 194.185.760. Ketiga total asset bank tersebut jauh diatas rata-rata total asset keseluruhan sampel bank.

Size atau ukuran bank menunjukkan skala usaha bank yang terlihat dari dari jumlah aset atau aktiva bank, bertambahnya aktiva bank menunjukkan bertambah besar investasi yang 
dilakukan.Semakin tinggi ukuran bank menuntut pendanaan lebih banyak yang sifatnya jangka panjang, salah satu pilihannya adalah melalui hutang, dimana alternatif pendanaan ini memiliki struktur biaya yang murah dibandingkan harus menerbitkan emisi saham baru. Pengaruh tidak langsung size terhadap struktur modal dengan nilai yang cukup besar jika size (ukuran bank) dihubungkan dengan struktur kepemilikan domestik yakni sebesar 7,75\%. Hal ini menunjukkan bahwa bank yang memiliki skala usaha besar dengan kepemilikan saham mayoritas domestik cenderung menggunakan hutang sebagai sumber pendanaannya.

\subsubsection{Pengaruh Risiko Kredit Terhadap Struktur Modal}

Total rata-rata kredit macet yang paling besar dimiliki oleh PT Bank Mandiri (Persero) yaitu sebesar Rp 10.930.498 (dalam jutaan) dan bank dengan rata-rata total kredit macet yang paling kecil adalah Bank of China Limited yaitu sebesar Rp 0 dan PT Bank Sahabat Purba Danarta yaitu sebesar Rp 1.673 (dalam jutaan). Sedangkan jika dilihat dari rasio Non Performing Loan (NPL), rasio yang paling kecil sebesar 0,00\% yaitu pada Bank of China Limited dan rasio NPL yang paling besar yaitu sebesar 16,89\% yakni pada PT Bank Mandiri (Persero). Sedangkan untuk rata-rata (mean) rasio NPL dari 216 pengamatan diatas diperoleh sebesar 3,26\%, hal ini menunjukkan bahwa rata-rata tingkat kredit macet pada bank sampel masih dibawah batas maksimum rasio NPL yang dinyatakan baik oleh Bank Indonesia yaitu sebesar NPL $\leq 5 \%$. Total rata-rata NPL yang paling kecil dimiliki oleh PT BPD Kalimantan Barat yakni sebesar 0,25\% dan total rata-rata rasio NPL terbesar dimiliki oleh PT BPD Sulawesi Tengah yakni sebesar 10,19\%.

Hasil estimasi menunjukkan Risiko Kredit berpengaruh negatif signifikan terhadap Struktur Modal Bank, dengan pengaruh total sebesar 1,52\%. Artinya bahwa semakin besar nilai risiko kredit, maka nilai DER akan turun atau bank akan mengurangi sumber pendanaan dari hutang. Hasil penelitian ini sejalan dengan hasil penelitian Darwanto (2008). Sedangkan Gropp dan Heider (2009) menemukan bahwa risiko asset dan risiko pasar akan berpengaruh negatif terhadap struktur modal.

Tingkat risiko kredit ini memiliki pengaruh yang cukup signifikan terhadap kemampuan bank untuk dapat menyediakan dana. Risiko kredit yang tinggi yang dilihat dari besar tingkat kredit macet dari suatu bank, dapat menurunkan tingkat kepercayaan masyarakat, yang menyebabkan bank mengalami kesulitan dalam penghimpunan dana dari pihak ketiga, sehingga mengurangi sumber pendanaan dari hutang. Pengaruh tidak langsung risiko kredit terhadap struktur modal dengan nilai yang cukup besar dihubungkan dengan struktur kepemilikan pemerintah yakni sebesar 1,14\%.

\subsubsection{Pengaruh Beban Manajemen Terhadap Struktur Modal}

Rata-rata total cost yang paling besar terdapat pada PT Bank Mandiri (Persero) yaitu sebesar Rp 22.748.811 (dalam jutaan) dan yang paling kecil terdapat pada PT Bank Sahabat 
Purba Danarta yaitu sebesar Rp 15.524 (dalam jutaan). Sedangkan jika dilihat dari rasio beban manajemen, rasio yang paling kecil terdapat pada PT Bank Maybank Indocorp yaitu sebesar 0,871\%. Dan rasio yang paling besar terdapat pada Bank Akita/PT Bank Barclay Indonesia yaitu sebesar 40,05\%. Rata-rata rasio beban manajemen dari 54 bank sampel diperoleh sebesar $8,79 \%$, hal ini artinya bahwa rata-rata bank sampel mengeluarkan beban manajemen sebesar $8,79 \%$ dari total asset yang dimiliki. Total rata-rata beban yang cukup besar berasal dari beban bunga sebesar 49,04\% dari rata-rata total cost, beban operasional sebesar 38,94\% dari total cost, dan sisanya 12,02\% berasal dari beban Penghapusan Aktiva Produktif (PPA) dan Beban Komitmen dan Kontingensi.

Hasil pengujian parsial menunjukkan bahwa Beban Manajemen bank berpengaruh positif signifikan terhadap Struktur Modal Bank, dengan total pengaruh sebesar 8,43\%. Artinya bahwa ketika variabel beban manajemen ini meningkat ditunjukkan oleh meningkatnya total cost terhadap peningkatan aktiva yang dimiliki oleh perusahaan, maka secara bersamaan ada kecenderungan makin meningkatnya rasio leverage bank. Hasil ini sejalan dengan penelitian yang dilakukan oleh Titman \& Wessel (1988) dan Darwanto (2008).

Apabila perusahaan lebih banyak menggunakan hutang (debt) dari pada ekuitas dalam memenuhi kebutuhan dananya, maka hal ini akan mendorong meningkatnya biaya atau beban tetap perusahaan dan hal ini akan memberikan kontribusi terhadap meningkatnya beban tetap total, berupa biaya bunga yang harus dibayar bank. Pengaruh tidak langsung beban manajemen terhadap struktur modal dengan nilai yang cukup besar jika beban manajemen dihubungkan dengan struktur kepemilikan domestik yakni sebesar 4,82\%. Hal ini menunjukkan bahwa bank yang memiliki beban/biaya manajemen yang besar dengan kepemilikan saham mayoritas domestik cenderung menggunakan hutang sebagai sumber pendanaannya.

\subsection{Hasil Analisis Jalur untuk Persamaan Struktur II}

Persamaan struktur II dalam model penelitian ini adalah untuk mengetahui besar pengaruh Struktur Kepemilikan Bank (kepemilikan pemerintah, domestik, asing), Karakteristik spesifik Bank (profitabilitas, ukuran bank (size), resiko kredit dan beban manajemen)dan Struktur Modal terhadap Fungsi Intermediasi Bank.

Nilai koefisien determinasi $\left(R^{2}\right)$ dari model yang diestimasi adalah sebesar 0,270 atau $27,0 \%$. Nilai ini relatif kecil yang menunjukkan bahwa variabilitas fungsi intermediasi bank (LDR) dapat dijelaskan oleh variasi variabel struktur kepemilikan bank pemerintah, domestik, asing, karakteristik spesifik bank yaitu profitabilitas, ukuran bank (size), resiko kredit, beban manajemendan struktur modal, sebesar 27,0\%. Sedangkan sisanya 73,0\% dipengaruhi oleh faktor-faktor lain diluar model ini². Untuk mengetahui apakah model diatas sudah benar,

2 Penulis menyadari bahwa model ini masih memerlukan pengembangan dan menjadi agenda penelitian lebih lanjut. 
maka diperlukan uji hipotesis yaitu uji F. Hasil perhitungan menunjukkan struktur kepemilikan pemerintah, domestik, asing, karakteristik spesifik bank yaitu profitabilitas, ukuran bank (size), resiko kredit, beban manajemendan struktur modal berpengaruh secara simultan terhadap fungsi intermediasi bank.

Sama halnya dengan persamaan struktur 1, pada persamaan struktur II juga dilakukan uji hipotesis secara parsial untuk melihat pengaruh secara parsial variabel-variabel X (Struktur kepemilikan, karakteristik spesifik bank) dan variabel $Y$ (struktur modal) terhadap fungsi intermediasi bank(Z).

Untuk uji hipotesis parsial variabel struktur kepemilikan pemerintah, domestik, asing, profitabilitas, ukuran bank (size), resiko kredit, dan beban manajemen tidak memiliki pengaruh yang signifikan. Hal ini berarti bahwa apabila terjadi perubahan sedikit saja pada variabel struktur kepemilikan dan karakteritik specific bank tidak secara langsung mempengaruhi fungsi intermediasi bank, sehingga pengaruhnya tidak dapat digeneralisir terhadap seluruh populasi bank konvensional di Indonesia. Namun variabel-variabel tersebut diatas memiliki pengaruh tidak langsung terhadap fungsi intermediasi bank melalui hubungannya dengan struktur modal.

Dari hasil perhitungan koefisien jalur, hanya variabel struktur modal yang memiliki pengaruh langsung signifikan terhadap fungsi intermediasi bank, yakni sebesar 12,18\%, dengan arah koefisien negatif dan pengaruh totalnya sebesar 13,846\%. Hasil ini mengindikasikan bahwa semakin besar rasio hutang terhadap ekuitas (DER) maka rasio fungsi intermediasi bank (LDR) akan semakin menurun. Atau dengan kata lain, fungsi intermediasi bank melalui penyaluran kredit akan meningkat jika sumber pendanaan dari ekuitas semakin ditingkatkan. Hal ini sejalan dengan hasil penelitian Kishan \& Opiela (2000) yang menyatakan bahwa penyaluran kredit dipengaruhi oleh penambahan ekuitas (modal sendiri) dan juga hasil penelitian Buchory (2006) yang menyatakan bahwa fungsi intermediasi bank dipengaruhi oleh struktur modal yang berasal dari ekuitas. Dan hal ini juga sejalan dengan teori yang dikemukakan oleh Rose (2010) bahwa struktur modal merupakan faktor kritis yang perlu diperhatikan oleh manajemen bank dalam melaksanakan fungsi intermediasinya untuk membangun kepercayaan masyarakat dan juga untuk mengantisipasi resiko yang terjadi.

Namun hasil ini bertentangan dengan Inderst \& Mueller (2008), yang mengemukakan bahwa asumsi tanpa adanya regulasi, penyaluran kredit beresiko tinggi dapat dilakukan dengan meningkatkan leverage rasio dari hutang. Sedangkan perbankan di Indonesia masih berada dalam regulasi atau pengawasan/kontrol yang cukup ketat yang diberikan oleh otoritas moneter dalam hal ini Bank Indonesia.

Sedangkan untuk pengaruh tidak langsung, jika dibandingkan dengan variabel $X$ lainnya, variabel struktur kepemilikan oleh asing $\left(X_{3}\right)$ dan profitabilitas $\left(X_{4}\right)$ memiliki pengaruh tidak langsung cukup besar terhadap fungsi intermediasi bank melalui hubungannya dengan struktur 
modal yakni sebesar 1,33\% dan 1,20\%. Hal ini mengindikasikan bahwa bank dengan struktur kepemilikan asing dengan struktur modal yang cenderung berasal dari ekuitas, memiliki fungsi intermediasi yang lebih tinggi yakni dengan tingkat rasio LDR yang cukup besar. Dan bank yang memiliki tingkat profitability (keuntungan) yang besar, struktur modalnya akan cenderung menggunakan ekuitas lebih besar, sehingga fungsi intermediasi bank juga meningkat dengan rasio LDR yang lebih besar.

Berbeda dengan yang dikemukakan oleh Atif Mian (2003) yang menyatakan bahwa bank domestik lebih cenderung agresif dalam menempatkan dananya dalam bentuk kredit, karena keunggulan yang dimiliki yakni terkait dengan "soft information" yang membuat bank meminjamkan lebih besar dengan tingkat bunga tinggi. Namun hal ini dapat diterima, karena jika dilihat lebih dalam bahwa sampel bank dengan struktur kepemilikan yang dikuasai oleh asing yang terdapat dalam penelitian ini, sebagian besar masuk kedalam kategori bank swasta domestik (BUSN Devisa) yang memiliki ukuran bank atau nilai total asset yang cukup besar dan sudah gopublic. Seperti PT Bank CIMB Niaga, Tbk, PT Bank ICB Bumi Putera Indonesia, Tbk, PT Bank Nusantara Parahyangan, Tbk, PT Bank Danamon,Tbk, PT Bank Internasional Indonesia, Tbk, PT Bank NISP, Tbk, PT Bank UOB Buana, Tbk.

\section{KESIMPULAN}

Paper ini merupakan penelitian empiris terhadap 54 bank umum konvensional di Indonesia periode pengamatan 2006-2009. Kesimpulan pertama yang dapat ditarik adalahstruktur kepemilikan pemerintah, domestik, asing, profitabilitas, ukuran bank (size), risiko kredit dan beban manajemen secara simultan berpengaruh signifikan terhadap struktur modal. Kesimpulan kedua, struktur kepemilikan dominasi pemerintah, struktur kepemilikan dominasi domestik, struktur kepemilikan asing, profitabilitas, dan risiko kredit, berpengaruh negatif signifikan terhadap struktur modal bank. Padasisilain, ukuran bank (Size) dan beban Manajemen bank berpengaruh positif signifikan terhadap Struktur Modal Bank. Terkait dengan fungsi intermediasi perbankan, maka kesimpulan ketiga yang dapat ditarik adalah bahwa struktur kepemilikan pemerintah, domestik, asing, profitability, size, credit risk, expense management dan struktur modal berpengaruh secara simultan terhadap fungsi Intermediasi Bank.

Berdasarkan hasil penelitian dan analisis yang telah dilakukan, maka diajukan saransaran untuk kepentingan pengembangan operasional dan akademik. Terkait dengan yang pertama, saran yang dapat diberikan adalah :

1. Melihat besarnya pengaruh yang diberikan oleh struktur kepemilikan dan karakteristik spesifik bank terhadap struktur modal, maka sangat penting bagi bank-bank di Indonesia dan pemerintah untuk memperhatikan masalah ini untuk mengoptimalkan fungsi intermediasi bank terutama dalam meningkatkan pertumbuhan penyaluran kredit khususnya untuk sektor riil. 
2. Disarankan bagi bank-bank yang memiliki potensi cukup besar untuk berkembang untuk melakukan go public dalam rangka menambah modal, meningkatkan ekspansi kredit dan meningkatkan likuiditas, serta agar lebih transparan kinerjanya (market to corporate control) dengan tetap memperhatikan prinsip kehati-hatian.

3. Bagi bank terutama yang menjadi unit analisis penelitian ini, khususnya bank-bank domestik disarankan untuk lebih meningkatkan kinerjanya melalui peningkatan profitability dan mengurangi beban manajemen dengan melakukan efisiensi terhadap biaya operasional, agar dapat bersaing dengan bank kepemilikan asing atau campuran.

4. Pemerintah harus tetap memperhatikan kebijakan terhadap pendirian bank-bank kepemilikan asing, terutama bagi bank yang berstatus sebagai kantor cabang, karena hanya sebagian kecil bank asing yang memberikan kontribusi terhadap kinerja perbankan di Indonesia. Berbeda dengan kepemilikan bank campuran dan kepemilikan asing dalam bank swasta domestik, yang cenderung memberikan kinerja yang lebih baik dengan kontrol yang lebih baik.

Terkait dengan aspek akademik dan penelitian lebih lanjut, saran yang dapat diajukan adalah :

1. Perlu dibedakan adanya struktur kepemilikan bank yang belum dan sudah go public, sehingga unit analisisnya memberikan hasil dan penjelasan yang lebih mendekati atau mewakili unit analisis tersebut.

2. Perlu dipertimbangkan secara jelas, mengenai alternatif sumber pendanaan melalui utang, apakah yang dimaksudkan adalah obligasi, longterm debt, pinjaman subordinasi, atau offshore loans. Pengertian penambahan ekuitas juga harus jelas apakah penambahan modal disetor, initial public offering (IPO), right issue atau laba ditahan.

3. Perlu diteliti komposisi jenis kredit yang disalurkan (kredit investasi, kredit modal kerja dan kredit komsumsi), sehingga dengan jelas menunjukkan tingkat optimalisasi fungsi intermediasi bank, khususnya bagi pertumbuhan ekonomi sektor riil.

4. Model intermediasi perbankan yang digunakan dalam paper ini, memerlukan pengembangan mengingat koefisien determinasi yang kecil yakni hanya $27,0 \%$. 


\section{DAFTAR PUSTAKA}

Apostolik, Richard., Donohue C., Went, Peter (2009), Foundation of Banking Risk : An overview of Banking, Banking Risks, and Risk-based Banking Regulation, John Wiley \& Sons, Inc Athanasoglou, P.P., Brissmis, S.N., and Delis, M.D. "Banks-Specific, Industry-Specific, and Macroeconomic determinants of Bank Profitability" Working Paper Bank of Greece, 2005. Bathala, CT Moon, KR dan Rao, R.P. "Managerial ownership, debt policy, and the impact of institutional holding: An agency perspective" Financial Management, 1994, p.38-50

Basar, Adhy., Ismady, Ishan. "Kondisi Perbankan 2009 dan Prospek 2010", EconomicReview, Desember 2009, No. 218.

Bikker, Jaap., Wesseling, Sandra., "Intermediation, Integration and Internalisation : A survey

On Banking in Europe", Occasional Studies De Nederlandsche Bank, Vol. I No. 3, 2003.

Brigham, Eugene F \& Erhardt, Michael C. (2005), Financial Management: Theory and Pratice, Eleventh Edition. Thomson Corporation, South Western.

Brigham, Eugene F \&Houston, Joel. (2003), Fundamentals of Financial Management, Tenth Edition. Thompson Southwestern.

Buchory, Herry Achmad, "The Effect Implementation of Financial Intermediary Function, Risk Management Application and Bank Capital Structure on Banking Financial Performance", Disertasi, Fakultas Ekonomi Padjadjaran, 2006.

Darwanto, Sony Aji, "The effect Macro Economic Conditions and Bank Specific on the Capital Structure and Source of Funding Choice Decision of Banking Industry Indonesia", Disertasi, Fakultas Ekonomi Padjadjaran, 2008.

Diamond, Douglas W., Rajan, Raghuram G., "Theory Of Bank Capital", The Journal of Finance,2002, Vol. 55 No.6 pp 2431-2465

Douma S, George, Rejie, Kabir Rezaul, "Foreign and Domestic Ownership, Business Groups and Firm Performance from ALarge Emerging Market", 2002, Tilburg University The Netherlands. Ghozali, Imam, (2005), Aplikasi Analisis Multivariate dengan Program SPSS, Badan Penerbit UNDIP, Semarang.

Gitman, Lawrence J. (2009), Principles of Managerial Finance, Twelfth Edition, The Addison Wesley Publishing.

Gujarati, Damodar N. (2006), Dasar-dasar Ekonometrika, edisi Ketiga, Penerbit Erlangga, Jakarta Hadad, Muliaman D, et.al., Fungsi Intermediasi Bank Asing dalam Mendorong Pemulihan Sektor

Riil Indonesia, ResearchPaper, Biro Stabilitas Sistem Keuangan, 2004, Bank Indonesia.

Hempel, George H, Simonson Donal, Colehan Alan B. (1999), Bank Management Text and

Cases, New York, John Wiley \& Son Inc. 
Inderst, Roman., Mueller, Holger., "Bank Capital Structure and Credit Decisions", Journal of Financial Intermediation, 2008, No. 17 pp. 295-314.

Jonni M., Adler Haymans M,. 2009. Ekonomi Keuangan dan Kebijakan Moneter, Penerbit Salemba Empat, Jakarta.

Jensen, M.C., Meckling, W.H., "Theory of the Firm : Managerial Behaviour, Agency Costs and

Ownership Structure", Journal of Financial Economics, 1976, Vol. 3, pp.305-360.

Kishan, Rudy P, Opiela, Timothy P., "Bank Size, Bank Capital and the Bank Lending Channel" ,Journal of Money, Credit and Banking, 2000, Vol. 32 No. 1 pp.121-141

Koch, Timothy W, Mac Donald, S. Scot. (2000), Bank Management, Fourth Edition, Orlando,

The Dryden Press, Harcourt Brace College Publishers.

Mandala, Manurung., Rahardja Prathama. (2004), Uang, Perbankan, dan Ekonomi Moneter, Penerbit Fakultas Ekonomi Universitas Indonesia.

Marques, Manuel O., Santos, Mario C., "Capital Structure and Determinants : Evidence from the Portuguese Banking Industry", November 2003.

Mian, Atif., "Foreign, Private Domestic, And Goverments Banks : New Evidence from Emerging Markets", Graduate School of Business, University of Chichago, Chichago.

Myers, Stuart. "The Capital Structure Puzle", Journal of Finance,2003, Vol. 39. July, 1984 Peirson, Graham. (2006), Business Finance, Ninth Edition. McGraw-Hill Australia PTy Limited Riduwan, Kuncoro, Engkos Ahmad, (2008), Cara Menggunakan dan Memaknai Analisis Jalur (PathAnalysis), Penerbit Alfabeta, Bandung.

Rose, Peter S., Hudgins, Sylvia C. (2010), Bank Management \& Financial Services, McGraw-Hill International Edition, New York.

Saunders, Antony, Garnett M. Millon., (2008), Financial Institutions Management : A Risk Management Approach,Sixth Edition, Mc Graw-Hill International Edition, New York.

Scholtens, Bert., Wensveen, Dick., "The Theory of Financial Intermediation: An Essay on What

It Does (Not) Explain", The European Money and Finance Forum, Vienna, 2003.

Siamat, Dahlan. (1999), Bank dan Lembaga Keuangan Lainnya, Penerbit Fakultas Ekonomi Universitas Indonesia

Sugeng, B., "Pengaruh Struktur Kepemilikan dan Struktur Modal terhadap Kebijakan Inisiasi Dividen di Indonesia", Jurnal Ekonomi Bisnis, Maret 2009, Tahun 14, Nomor 1.

Sugiarto, Agus. 2004. Mengapa Modal Minimum Bank Harus Rp 100 Miliar? Kajian Stabilitas Keuangan, Bank Indonesia, Jakarta.

Sugiyono, (2011), Metode Penelitian Bisnis, Penerbit CV Alfabeta, Bandung.

Taswan. 2010. Manajemen Perbankan : Konsep, Teknik dan Aplikasi, Edisi II, UPP STIM YKPN, Yogyakarta.

Titman, Sheridan., Wessels Roberto, "The Determinants of Capital Structure Choice", The Journal of Finance, 1988, Vol. 43 No. 1 pp 1-19 
Halaman ini sengaja dikosongkan 